\title{
The Investigation of Relationship between Religious Attitudes and Attachment Styles among Iranian Students
}

\author{
Sedigheh Sakaki* , Toozandehjani Hassan",\# \\ Department of Psychology, Faculty of Humanities, Neyshabur Branch, Islamic Azad University, Neyshabur, Iran \\ Email: "H.Toozandehjani@ymail.com
}

How to cite this paper: Sakaki, S. and Hassan, T. (2017) The Investigation of Relationship between Religious Attitudes and Attachment Styles among Iranian Students. Open Journal of Psychiatry, 7, 115-122. https://doi.org/10.4236/ojpsych.2017.72011

Received: November 25, 2016

Accepted: April 27, 2017

Published: April 30, 2017

Copyright $\odot 2017$ by authors and Scientific Research Publishing Inc. This work is licensed under the Creative Commons Attribution International License (CC BY 4.0).

http://creativecommons.org/licenses/by/4.0/

\begin{abstract}
During recent years, A new tendency has appeared among psychologists to pay more attention to the influence of family, cultural and social factors on the human personality and his internal needs. This tendency is in favor of more attention to religion for treatment of mental health, thought and mental disorders. The type of researches: this research is a correlation and post-event (causative) which has done with the purpose of studying the relationship between religious attitudes with attachment styles for the students. So a sample of 60 students of humanitarian sciences majors at the Islamic Azad University of Neyshabour randomly selected classical (according to the results of attachment style inventory, completed by 150 students). The religious attitudes of subjects were tested by Alport religious orientation inventory and their attachment style by Shiver and Hezen's adult attachment test and were tested according to the results of descriptive and inferential statistics methods. The results of research indicated that for the subjects which have safe attachment style, their religious attitudes are internal. For the subjects which have unsafe attachment style (evidential, ambivalent), their religious attitudes are external. And also the subjects with ambivalent unsafe attachment style have internal religious attitudes in comparison with evidential unsafe attached persons. So, it can be said person's attachment style is affected by their religious attitudes. As related to the attained results and comparing them with the results of past researches, it can be said that people with internal religious orientation and safe attached persons have confidence in others (especially to themselves) because of some personal characteristics. So, there is no reason for fear or for connivance of what they want and naturally will have an attitude which is needless to show pretension and hypocrisy. As a result, their religious attitude score in internal scale is more than external scale.
\end{abstract}




\section{Keywords}

Religious Attitudes, Attachment Styles, Iranian Students, General Psychology

\section{Introduction}

Human beings, from the beginning to the end of any age and any situation, need affection and love of parents, other family members and his all fellow-creatures. Human has to enjoy the affective, social, economic sense and other psychical and mental aspects, and needs to belong to a group of houses, family and etc. [1].

[2] has emphasized the causative relationship between individual experiences with parents and individual capacity and ability in the establishment of emotional connections in the future. He believed that attachment theory is not only infant change theory, but also lifetime change theory.

[3] believed although attachment behavior can observe highly in infant period, it can observe in lifetime rotation and especially the urgencies too.

[4] has reported that there is a person who concerns you and thinks about you.

In any age and any situation there is an important role and he is as a safe base. In attachment formation process [5] brings near the child to mother, the system of feelings and attachment behaviors, and keeps him/her safe from danger.

[6] [7] understood the people who have internal religion of attitude experienced less anxiety, tension and mental pressure compared with the persons who have external religion of attitude.

Numerous researches [8] have indicated the people who have avoidant and ambivalent unsafe attachment style, mostly have no trust to others and themselves. This characteristic causes that they sometime concern and behave anxiously and have less truthful behavior. These results have been reported in the researches of [9] [10].

The results of [11] research indicate that avoidant unsafe persons have external religious attitude in comparison with the ambivalent unsafe persons. The lack of self-confidence in the analysis of mental-interior basses, usually destroys the favor confronting power of situation and indicates a kind of psychological extreme poverty for these persons. These results are observed in the researches of [12] [13].

Numerous researches [14] [15] indicate that the persons who have unsafe interest style, usually have no personality development because of fear from punishment and others reproach and have tendency to receive social privilege/points, so they have tool tendency to religion.

The results of [16] [17] indicate that the persons who have ambivalent unsafe attachment style for receiving peace, draw others attention, because of weakness in suitable connecting with other persons and having concern about not being accepted by them, and these kind of persons mostly don't trust others. 
The results of [18] researches indicate that the persons who have ambivalent unsafe attachment style have problems in marriage adjustment and internal attitude.

It's believed that human beings in the lifetime receive peace and safety by religion. Believe in God is the greatest shelter that relaxes to the human beings psyche.

[19] also says that the religious and nonreligious people experience the same mental pressure rate, but the religious people can better check with lifetime negative events and mental stressful factory. The religious people use from religion for checking with mental pressure well. Do their reaction to mental pressure influence on factors like, safe attachment in effect of social support and person hard working?

And now, we have this question, if the persons have deep attachment to unlimited power of God that always is in use and can trust it, will it affect on the effective and vocational attachment, and will the kind of attachment of every person affect on religious attitude or not?

Because every culture brings the methods for the persons and the persons will have influence of each others, it was necessary to study the attachment style and their religious attitude between some of them to indicate the influence of attachment style on their religious attitudes. In this investigation 3 theories were studied: 1) the subjects having safe attachment style, than the subjects having unsafe attachment style (avoidant and ambivalent) have an internal religious attitude. 2) The subjects having unsafe attachment style (avoidant and ambivalent) than the subjects having safe attachment style have an external religious attitude. 3) The subjects having ambivalent unsafe attachment style than the subjects having avoidant unsafe style have an internal attitude.

\section{Methodology}

This research is a correlation and causative (post-event) which has done with the purpose of studying attachment styles relationship with religious attitudes of students. At first, the inventory of adult Shiver and Hezen attachment style with Alport religious attitude inventory among the subjects (200 people who had been randomly classical and cluster selected) distributed and completed. Then from statistical society of this research included all of female students of humanitarian sciences major of Neyshabour Azad University, a sample of 60 people (based on the toppest Alport religious of attitude and attachment style inventory marks) had been selected. From this number, 30 people had safe attachment and 30 people had unsafe attachment (15 people had avoidantial unsafe attachment style, 15 people had ambivalent unsafe attachment style). After that the results were analyzed via descriptive and explanatory statistical methods.

In this research, 2 inventories are used: 1) Attachment style inventory: This exam is a one-factor self-basement instrument that includes 3 descriptive statement from the person feeling about easiness or friendship in the relations). With applying a 9 degrees grading scale (from complete agreement to complete disagreement), it's wanted from participants to score each statement according to 
the degree that is based on their feelings and experiences in the relationships. The analyses that is done on classification tool, lead to decision making in person attachment style, while the analyses that is done on scoring measures lead to decision making about the proportion of dimension degrees (that is security, avoidance, ambivalent) that exist in all persons much or less.

2) Alport religious classification inventory Alport made a 20 degree scale which 11 options of item related to external attitude and 9 options of it are related to internal attitude. Figen made a 21 options version from this scale that all of Alport options were selected in. One another option was added to it. According to Alport researches the correlation between internal religious attitudes with external religious of attitude options was -0.21 . In some of other studies such as the studies that were done by Figen, the correlation between internal and external religious attitudes was -0.20 that is so close to the correlation calculated by Alport. The validity of the scale has been properly reported by [20]. In a research that was calculated via Kranbakh Alpha by Tabatabaee, Alahyari and Mokhtari, the Alpha was reported equivalent to 0.712 .

\section{Results}

For studying the theories of investigation, the data were analyzed by statistical methods such as correlation coefficient and then we will study the meaningfulness of this coefficient by t-test. At first is reported the summary results of the subjects demographic characteristics and then indicates the analytical results (Tables 1-7).

According to t-calculated (5.33) is more than t-standard (2.048), so the assumption of being zero is rejected. On the other hand, the correlation coefficient has meaningful between safe attachment style and internal religious attitude. So,

Table 1. Mean and standard deviation of the subjects demographic particulars.

\begin{tabular}{cccccc} 
Variables & numbers & \multicolumn{2}{c}{ age } & \multicolumn{2}{c}{ education } \\
\cline { 3 - 6 } Groups & & $\mathrm{x}$ & $\mathrm{s}$ & $\mathrm{x}$ & $\mathrm{s}$ \\
\hline Safe attached & 30 & 6.35 & 6.57 & 14.8 & 0.9 \\
Unsafe attached & 30 & 35.2 & 8.03 & 14.9 & 0.9 \\
Unsafe attached (avoidant) & 15 & 35.08 & 8.12 & 14.9 & 0.9 \\
Unsafe attached (ambivalent) & 15 & 35.7 & 8.08 & 14.9 & 0.9 \\
\hline
\end{tabular}

Table 2. Agreement table of subject numbers in attachment group in terms of educations.

\begin{tabular}{cccccc}
\hline Course & mathematic & $\begin{array}{c}\text { Empirical } \\
\text { sciences }\end{array}$ & $\begin{array}{c}\text { Primary } \\
\text { education }\end{array}$ & $\begin{array}{c}\text { Islamic learning } \\
\text { and theology }\end{array}$ & total \\
Safe attached & 6 & 7 & 11 & 6 & 30 \\
Unsafe attached (avoidant) & 1 & 3 & 7 & 3 & 3 \\
Unsafe attached (ambivalent) & 4 & 5 & 21 & 13 & 60 \\
total & 11 & 15 & & & 15 \\
\hline
\end{tabular}


Table 3. Mean and standard deviation of numbers for 3 groups of attachment style and internal and external religious attitude.

\begin{tabular}{|c|c|c|c|c|c|c|}
\hline \multirow{2}{*}{$\begin{array}{r}\text { Attachment style } \\
\text { Safe attached }\end{array}$} & \multicolumn{2}{|c|}{$\begin{array}{l}\text { Internal religious } \\
\text { orientation scale }\end{array}$} & \multicolumn{2}{|c|}{$\begin{array}{c}\text { External religious } \\
\text { orientation scale }\end{array}$} & \multicolumn{2}{|c|}{ attachment scale } \\
\hline & $\mathrm{x}$ & s & $\mathrm{x}$ & s & $\mathrm{x}$ & s \\
\hline Unsafe attached (avoidant) & 36.2 & 5.42 & 27.1 & 4.22 & 7.23 & 1.65 \\
\hline Unsafe attached (ambivalent) & 27.4 & 6.94 & 40.7 & 3.91 & 7.68 & 1.30 \\
\hline total & 30.1 & 5.62 & 37.6 & 4.76 & 7.2 & 1.42 \\
\hline
\end{tabular}

Table 4. Correlation coefficient number for safe interest style and internal and external religious attitude.

\begin{tabular}{ccccccc}
\hline Variables & $\begin{array}{c}\text { numbers } \\
\text { (n) }\end{array}$ & $\begin{array}{c}\text { correlation } \\
\text { coefficient }(\mathrm{r})\end{array}$ & $\begin{array}{c}\text { Degree of } \\
\text { freedom }\end{array}$ & $\begin{array}{c}\text { Meaning } \\
\text { fullness }(\mathrm{p})\end{array}$ & t-calculated & t-standard \\
\hline $\begin{array}{l}\text { Subscale external } \\
\text { Subscale internal }\end{array}$ & 30 & 0.07 & 28 & 0.05 & 0.37 & 2.048 \\
\hline
\end{tabular}

Table 5. Correlation coefficient between unsafe attachment style number and internal and external religious attitudes.

\begin{tabular}{lcccccc}
\hline Variables & $\begin{array}{c}\text { numbers } \\
(\mathrm{n})\end{array}$ & $\begin{array}{c}\text { correlation } \\
\text { coefficient (r) }\end{array}$ & $\begin{array}{c}\text { Degree of } \\
\text { freedom }\end{array}$ & $\begin{array}{c}\text { Meaning } \\
\text { fullness (p) }\end{array}$ & t-calculated & t-standard \\
scales & 30 & 0.70 & 28 & 0.05 & 5.18 & 2.048 \\
Subscale external & 30 & -0.22 & 28 & 0.05 & -1.22 & 2.048 \\
Subscale internal & 30 & & & \\
\hline
\end{tabular}

Table 6. T-test results about unsafe attachment style (avoidant) and external and internal religious attitude.

\begin{tabular}{lcccccc} 
Variables & $\begin{array}{c}\text { numbers } \\
(\mathrm{n})\end{array}$ & $\begin{array}{c}\text { correlation } \\
\text { coefficient (r) }\end{array}$ & $\begin{array}{c}\text { Degree of } \\
\text { freedom }\end{array}$ & $\begin{array}{c}\text { Meaning } \\
\text { fullness (p) }\end{array}$ & t-calculated & t-standard \\
scales & 15 & 0.54 & 13 & 0.05 & 2.31 & 2.160 \\
Subscale external & 15 & -0.45 & 13 & 0.05 & -1.81 & 2.160 \\
\hline
\end{tabular}

Table 7. T-test results about ambivalent unsafe attachment style and external religious attitude.

\begin{tabular}{lcccccc} 
Variables & $\begin{array}{c}\text { numbers } \\
\text { (n) }\end{array}$ & $\begin{array}{c}\text { correlation } \\
\text { coefficient (r) }\end{array}$ & $\begin{array}{c}\text { Degree of } \\
\text { freedom }\end{array}$ & $\begin{array}{c}\text { Meaning } \\
\text { fullness (p) }\end{array}$ & t-calculated & t-standard \\
scales & 15 & 0.60 & 13 & 0.05 & 2.70 & 2.160 \\
Subscale external & 15 & 0.13 & 13 & 0.05 & 0.47 & 2.160 \\
\hline
\end{tabular}

the claim of researcher is confirmed about meaningful relations between safe attachment style and internal religious attitude.

According to t-calculated (5.8) is more than t-standard (2.048), so the assumption of being zero is rejecter. On the other hand, the claim of researcher is confirmed about meaningful relation between unsafe attachment style and ex- 
ternal religious attitude. So, there is a meaningful correlation between unsafe attachment style and external religious attitude.

According to $t$-calculated $(t=2.31)$ is more than $t$-standard $(t=2.160)$, so the assumption if being zero is rejected. On the other hand, there is a meaningful correlation between unsafe attachment style and external religious attitude. So the claim of researcher is confirmed about external religious attitude for the group having avoidant unsafe attachment style.

According to, $\mathrm{t}$-calculated (2.70) is more that $\mathrm{t}$-standard (2.160). So the assumption of being zero is rejected and the claim of researcher is confirmed about internal religious attitude in the persons having ambivalent attachment style.

\section{Discussion}

As related to the attained results and compared them with the results of researches [20] [21], it can be said that the persons with internal religious orientation experience less mental pressure, and anxiety compared with the persons having external religious orientation.

These results with the results of present research are agreement. [22] has indicated that there is a negative correlation between the ambivalence scale numbers and the marriage adjustment, so unsafe persons have problems in the marriage adjustment and in the internal attitude too.

Because of moral particulars, safe attached persons can trust than all the persons, especially than themselves, and have no fear about desired things consequently.

And naturally they have attitude, and no need to affectation. And for hypocrisy, that's why their religious attitude number in internal scale is more than external scale that is in agreement with the results of present research [12] [13] [19] [20] [23].

These results are in agreement with the results of present research too.

The results of these research indicated that the subjects having safe attachment style have internal religious attitude, in spite that persons having external religious attitude are more unsafe attached persons and the main reason of this result is self-confidence and others confidence. Those are two main characteristics of safe persons. These results are in agreement with the results of [1] [3] [7].

Avoidant unsafe persons have more external attitude, because the lack of selfconfidence and others confidence are two main particulars of unsafe persons [13]. The lack of self-confidence in the analysis of mental-interior basis, usually destroys the desired confronting power of situation and indicates a kind of psychological extreme poverty for unsafe persons. These results are in agreement with the result of [14] [15].

The unsafe persons usually have no personality development because of fear from punishment and others reproach and have tendency to receive social privilege/points, so they have tool tendency to religion, and they have defect in their faith [2] [3] [4]. 
In spite of the persons having ambivalent unsafe attachment style, the persons having avoidant unsafe attachment style, have no self-others and they try to earn peace by others attracting attention, because of their moral character they cannot connect with others and they are always concerned to be alone.

These results are also in agreement with the results of [5] [6] [8] [11].

\section{References}

[1] Baron, A. and Robert, D. (2003) Social Psychology. 6th Edition, Printed in United State of America.

[2] Biabangard, E. (1994) The Increasing Methods of Self-Esteem in the Children and Adolescence. Guardians and Educators Association Publication, Tehran.

[3] Bigdeli, I. (1994) Experimental Investigation of Attribution Style in Learned Distress. Psychology Researches, Forth Period, Number 3, 4, 60-71.

[4] Bowlby, J. (1969, 1973, 1980) Attachment (Vol. 1): Attachment and Loss. Basic Book, New York.

[5] Hall, B. (2005) Indexes to Assess Social and Personal Development and the Impact of College. College Student Journal, 30, 502-515.

[6] Ali Pour, B. and Beygi, M.M. (1997) Academic Motivation. Compilation and Investigation Group of Ali Pour Quick. Reading Institute, Tehran.

[7] Ballard, E. (2004) Effects of a Social Skills Training Program on Social Adjustment of Persons with Head Injuries. Illinois Institute of Technology, DAL. B 54/07, 3844.

[8] Carver, P., Vunger, J. and Derry, D. (2003) Gender Identity and Adjustment in Middle Childhood. Sex Roles, 49, 95-109. https://doi.org/10.1023/A:1024423012063

[9] Goodstein, L.D. and Lanyon, R.I. (2005) Adjustment Behavior and Personality. Arizona State University, Tempe.

[10] Ahadi, H. (1995) The Investigation of Mule and Female Teachers-Student Causative Documents in Mashhad. Tarbiat Moallem Centers. The Section Part of Education and Learning, Forth Period, Number 43, 44, 105-122.

[11] Greenberg, G.Y. (2006) The Effect of Relationship Enhancement Program on Marital Communication and Self-Esteem. Journal of Applied Social Sciences, 5, 78-94.

[12] Karimi, Y. (1996) Social Psychology (Theories, Concepts and Applications). Arasbaran Publications, Tehran.

[13] Lassiter, E. (2004) An Assessment of the Relationship between Student Perception of School Effectiveness and Student Achievement and Social Adjustment in Zoned Comprehensive Public High Schools. Morgan State University, DAI-A 55/07, 1767.

[14] Taghi Pour, A. (1999) The Influence Document Relearning on the Attributional Style, Self-Confidence, Endurance and Performance. Master of Arts (M.A.) Thesis, Medical Sciences and Cure Services University of Iran.

[15] Blake, T.R. and Rust, J.O. (2002) Self-Esteem and Self-Efficacy of College Students with Disabilities. College Student Journal, 36, 214.

[16] Mendonca, L. (2006) Group Counseling: Its Effects on the Perception of Self and Others on the Adjustment of Students from India. The University of Michigan, DAI-A 42/09, 3873.

[17] Jackson, J.W. and Smith, E.R. (1999) Conceptualizing Social Identity: A New Framework and Evidence for the Impact of Different Dimensions. Personality and Social Psychology Bulletin, 25, 120-135. https://doi.org/10.1177/0146167299025001010 
[18] Pelham, B.W., et al. (2008) Self-Esteem Enhancement with Children and Adolescent. Pergamum Press, New York.

[19] Pep, Ellis, et al. (1995) The Increasing of Self-Respect in the Children and Adolescence. Roshd Publications, Tehran.

[20] Rasel, et al. (2001) Social Psychology (A New Approach to Attributional and etc). Astan-e Ghods-e-Razavi Publications, Mashhad.

[21] Silverstone, P.H. (2007) Low Self-Esteem in Different Psychiatry Conditions. British Journal of Clinical Psychology, 30, 185-188. https://doi.org/10.1111/j.2044-8260.1991.tb00936.x

[22] Weiss (2004) The Effect of Relationship Enhancement Program on Marital Communication and Self-Esteem. Journal of Applied Social Sciences, 5, 78-94.

[23] Weiten, W. and Lloyd, M.A. (2007) Psychology Applied to Modern Life: Adjustment in the 90s. Brook/Cole Publishing Company, Pacific Grove, CA.

Submit or recommend next manuscript to SCIRP and we will provide best service for you:

Accepting pre-submission inquiries through Email, Facebook, LinkedIn, Twitter, etc. A wide selection of journals (inclusive of 9 subjects, more than 200 journals)

Providing 24-hour high-quality service

User-friendly online submission system

Fair and swift peer-review system

Efficient typesetting and proofreading procedure

Display of the result of downloads and visits, as well as the number of cited articles

Maximum dissemination of your research work

Submit your manuscript at: http://papersubmission.scirp.org/

Or contact ojpsych@scirp.org 